\title{
THE VIEWS OF THE TOURISM VILLAGE MANAGERS ON THE GREEN EVENT CONCEPT IN BALI
}

\author{
Christantius Dwiatmadja ${ }^{1 *}$, I Putu Astawa ${ }^{2}$, Tjokorda Gde Raka Sukawati ${ }^{3}$ \\ ${ }^{1}$ Satya Wacana Christian University, Diponegoro street 52-60, Salatiga, 50711, Indonesia \\ ${ }^{2}$ Politeknik Negeri Bali, Uluwatu Street No.45, Jimbaran, South Kuta, Badung Regency, Bali 80361, Indonesia \\ ${ }^{3}$ Universitas Udayana, Jalan P.B. Sudirman, Dangin Puri Klod, Denpasar, Bali 80234, Indonesia \\ *Corresponding author, email: christantius.dwiatmadja@staff.uksw.edu
}

\begin{abstract}
This research describes the views of the village tourism managers on the green event model developed by the Bali State Polytechnic. Data were collected through questionnaires sent by email and by post to village tourism managers. There are a hundred tourist villages planned to be developed in Bali and all are made research samples. The collected data were analyzed by using descriptive statistics. The results of the study indicate that the understanding of green aspects includes green foods, waste management, natural materials, and ecosystem is averagedly quite good. From the cultural aspect is very good, meaning that the culture practised by the community gives a strong impetus to keep the environment sustainable so that the harmonious relationship with nature, humans, and God is maintained through the activities in Tourism Villages. Other results indicate that an understanding related to the ecosystem, the green food, and the waste management needs a special attention to further improve understanding. Green event as an alternative product in supporting the tourist village is very much expected by the managers that will further be synergized with the existing culture. The combination of both green event and existing culture is quite unique and will constantly keep the concept of sustainable tourism.
\end{abstract}

Keywords: Green event, sustainable tourism, tourism village, culture.

\section{Introduction}

The awareness of the effect of climate changes on tourism practices has been improving (Becken \& Hay, 2007; Gössling \& Scott, 2008) and the same is the sustainability, which is also getting its importance tourism businesses (Font \& Harris, 2004; Murphy \& Price, 2005; Swarbrooke, 1998; Weaver, 2006). The event element also gives more focus on the green concept and even refers to a strategy to win business competition. Examples of the event are the 2000 Sydney Olympiad (Kearins \& Pavlovich, 2002) and the 2002 Manchester Commonwealth Games (Carlsen \& Taylor, 2003) as a more general exploration on the role and significance of the green element in the management of general sports events (Chernushenko, 1994). This condition was urged by the negative issue of the air pollution in 1998, so that it encouraged all the big events to include the green element and pollution as a very important issue.

The term 'green event' can be explained to be one that includes the element of sustainability in the practice of management and its operation. The sustainability here includes the environmental, economic, and socio-cultural responsibilities (Kapera, 2018). These three kinds of responsibilities become a basis in developing green tourism and require all aspects the tourism industry, such as tourists, companies, communities, and government to be involved actively (Astawa, 2018; Liu, Nijkamp, Huang, \& Lin, 2017).
The stakeholders' involvement in various countries in developing the green concept remains varied. It is affected by diverse factors, such as economic, sociocultural, political, and security (Mika, 2015).

Each country has been aware and agreed that the green concept should be given a broader meaning and be implemented by the inclusion of sustainability concept in the government programs in such a way that the community consciously participates in developing and maintaining a better environment for their future life. Developing awareness of sustainability in tourism sector is not a simple thing and needs costs for campaigning in order that the community may understand in depth the sustainability program or the green concept in every activity they are involved in (Mika, 2015; Astawa, Triyuni, \& Santosa, 2018). In developing countries, the communities are less concerned with developing environment that it becomes an issue. However, it is not completely true since more communities are less capable of giving attention to the environment through the culture they embrace (Astawa et al., 2018; Liu et al., 2017).

Indonesia is a developing country which has famous tourism spots worldwide, such as Bali. Bali has become a world tourist destination which puts culture in the front line as a basis for tourism. Bali is also a place for big events or summit meetings, such as economic, political, cultural, and other sectoral meetings. This condition motivates them to tidy up and keep their good image in order to retain their 
competitive power. One of the things they do is empowering the villages by making them tourism villages as an alternative product. The impact of the policy will be the future influx of tourists into their villages. The problem remains how the community's response to the tourism activity in their village would be like. A research finding gives clarification, that is, in Poland $61 \%$ of the tourists do not understand tourism sustainability (Szymańska, 2013) although the community has an important role in building up a village-based tourism (Mika, 2015; Astawa et al., 2018)

Bali planned to develop 100 tourism villages but not all went well with the government's expectation as a result of the fact that the village communities were not generally ready, except those at the village management level (Astawa et al. 2018). There is a tourism village which had been investigated in which its community has undertaken tourism activities, such as tracking, workshops, cooking classes, weddings, cultural attraction, i.e., the Pinge Village (Astawa, 2017; Astawa et al., 2018). The variety of tourism activities in the villages as well as the effort to consolidate the understanding of the green concept need a commonly compact understanding among the performers or agents of tourism village in order to assure the sustainability of the tourism. This research illustrates the views of the tourism village managers on the green event concept (Astawa et al., 2018), which is developed on the basis of the culture they belong to.

\section{Research Method}

This research uses two approaches, i.e., qualitative and quantitative approaches. In the qualitative stage, in-depth interviews were done to tourism village managers in Bali. Prior to the interviews, letters were sent out via email and post, saying a request for a discussion on the concept of green event which is developed on the basis of two concepts, namely green and culture (Astawa et al. 2018). The questions emphasize how the green concept is applied or environmentally friendly in carrying out events in the village. Relating to culture is emphasized in the cultural values of the community relating to the values of beliefs, relationships with fellow humans, and relations with the surrounding environment. As many as nine persons who are representatives of each regency and city serving as informants presented their views in clear details on green event. The average time for interviews was 65 minutes. The selection of the informants was based on the recommendation of the Tourism Village Forum who participated in the 2017 THK Word. Data collected were compared with the existing theory (Glaser \& Strauss, 2017) and coded using Miles and Huberman (1994). The result of the qualitative stage was used to make a questionnaire using five Likert scales, consisting of five aspects: Green food, Natural materials, Waste management, Ecosystem, and Culture (Astawa et al., 2018) and was tested to determine its validity and reliability in 30 tourism villages; the result of the test was valid and reliable.

The quantitative stage was initiated with the sending of the questionnaire by email and post to tourism village managers in 82 tourism villages, excluding 30 tourism villages which were used as questionnaire testing samples. The data collected were analyzed using the descriptive statistics (Sugiyono, 2010). The result of the validity and reliability of the questionnaire is described in Table 1 and Table 2.

Table 1

Result of Validity testing of the Research Variable

\begin{tabular}{|c|c|c|c|c|c|}
\hline Variables & Items & $r_{\text {count }}$ & Sig. & $r_{\text {table }}$ & Criteria \\
\hline \multirow[t]{4}{*}{$\begin{array}{l}\text { Green } \\
\text { food }\end{array}$} & $\begin{array}{l}\text { Eating } \\
\text { together on mats } \\
(\text { metegak })\end{array}$ & 0.883 & 0.000 & 0.378 & Valid \\
\hline & $\begin{array}{l}\text { Cooking traditional } \\
\text { foods }\end{array}$ & 0.787 & 0.000 & 0.378 & Valid \\
\hline & $\begin{array}{l}\text { Introducing kinds of } \\
\text { local vegetables and } \\
\text { fruits }\end{array}$ & 0.815 & 0.000 & 0.378 & Valid \\
\hline & Traditional drinks & 0.857 & 0.000 & 0.378 & Valid \\
\hline \multirow[t]{3}{*}{$\begin{array}{l}\text { Natural } \\
\text { Materials }\end{array}$} & $\begin{array}{l}\text { Cooking class with } \\
\text { existing materials in } \\
\text { the village }\end{array}$ & 0.893 & 0.000 & 0.378 & Valid \\
\hline & $\begin{array}{l}\text { Disusing or bringing } \\
\text { tools from plastic }\end{array}$ & 0.935 & 0.000 & 0.378 & Valid \\
\hline & $\begin{array}{l}\text { Making offerings with } \\
\text { natural materials }\end{array}$ & 0.874 & 0.000 & 0.378 & Valid \\
\hline \multirow{4}{*}{$\begin{array}{l}\text { Waste } \\
\text { manage- } \\
\text { ment }\end{array}$} & $\begin{array}{l}\text { Waste management to } \\
\text { make compost }\end{array}$ & 0.791 & 0.000 & 0.378 & Valid \\
\hline & $\begin{array}{l}\text { Processing animal } \\
\text { dunks for bio and } \\
\text { organic gases }\end{array}$ & 0.880 & 0.002 & 0.378 & Valid \\
\hline & $\begin{array}{l}\text { Making waste } \\
\text { vessels }\end{array}$ & 0.652 & 0.000 & 0.378 & Valid \\
\hline & $\begin{array}{l}\text { Processing } \\
\text { Kitchen wastes }\end{array}$ & 0.744 & 0.000 & 0.378 & Valid \\
\hline \multirow{4}{*}{$\begin{array}{l}\text { Ecosyste } \\
\text { m }\end{array}$} & Cultivating rice fields & 0.901 & 0.000 & 0.378 & Valid \\
\hline & $\begin{array}{l}\text { Identification of village } \\
\text { environment }\end{array}$ & 0.915 & 0.000 & 0.378 & Valid \\
\hline & Irrigation system & 0.864 & 0.000 & 0.378 & Valid \\
\hline & Using organic fertilizer & 0.781 & 0.000 & 0.378 & Valid \\
\hline \multirow[t]{3}{*}{$\begin{array}{l}\text { Tri Hita } \\
\text { Karana } \\
\text { Culture }\end{array}$} & $\begin{array}{l}\text { Community religious } \\
\text { activities (Prayer } \\
\text { rituals) }\end{array}$ & 0.672 & 0.000 & 0.378 & Valid \\
\hline & $\begin{array}{l}\text { Interaction with the } \\
\text { community by cultural } \\
\text { shows }\end{array}$ & 0.754 & 0.000 & 0.378 & Valid \\
\hline & $\begin{array}{l}\text { Introducing natural } \\
\text { preservation by } \\
\text { religious rituals }\end{array}$ & 0.921 & 0.000 & 0.378 & Valid \\
\hline
\end{tabular}


Table 2

Result of Reliability Test

\begin{tabular}{lccl}
\hline Variables & $\boldsymbol{r}_{\text {alpha }}$ & $\boldsymbol{R}_{\text {critical }}$ & Criteria \\
\hline Green food & 0.929 & 0.600 & Reliable \\
Natural Material & 0.947 & 0.600 & Reliable \\
Waste management & 0.978 & 0.600 & Reliable \\
Ecosystem & 0.980 & 0.600 & Reliable \\
Tri Hita Karana Culture & 0.931 & 0.600 & Reliable \\
\hline
\end{tabular}

\section{Result and Discussion}

Green event is a program which brings about sustainability of tourism involving environment preservation, which in turn affects economy and socioculture. Green event is an activity in tourism performed in the village where participants are directly involved in hands-on practices in green food, natural material, waste management, ecosystem, and tri hita karana culture in tourism villages (Dewi, Astawa, Siwantara, \& Mataram, 2017; Astawa et al., 2017).

The result of distributing questionnaires to the tourism village managers shows that $66 \%$ of the tourism village managers have undergraduate education and the rest are high school graduates. The average office time for the chairman of the managers is three years and those who are in the average age of 47 years cover $75 \%$, and the rest is 48 years and above. Viewed from the education of the managers, their education is very adequate for the implementation of the management concept in the village along with their productive ages, so that the development of green event in the tourism villages is openly running well. Higher education enables one to solve problems in a better way (Hastarini, 2005).

Perception on green food in the green event shows that they agree to the program which is done by utilizing traditional foods as serving meals in tourism activities. This condition is explained in Table 3 where the average perception from the respondents' answers is 4.48 or is close to the totally agree answer. Nature-based green foods are understood to be very significant in supporting green-based tourism activities. The result of this study gives support to the previous research in relation to the advantages of green food in health and events (Zhu, Li, Geng, \& Qi, 2013; Astawa et al., 2017).

The implementation of the event also used materials from the nature as in making ceremony equipment, and disuse of plastics. This concept gets support from the respondents who gave the average answers of 4.5 (Table 4), which is close to the totally agree answer. The result illustrates that the communities are consciously aware that environmentally friendly materials are important in a village tourism activity. The use of natural materials can become a way to create the green image in the villages. The community's attitude such as this has enhanced the development of sustainable tourism (Romão \& Neuts, 2017).

Table 3

Perception on Green Food in Tourism Villages

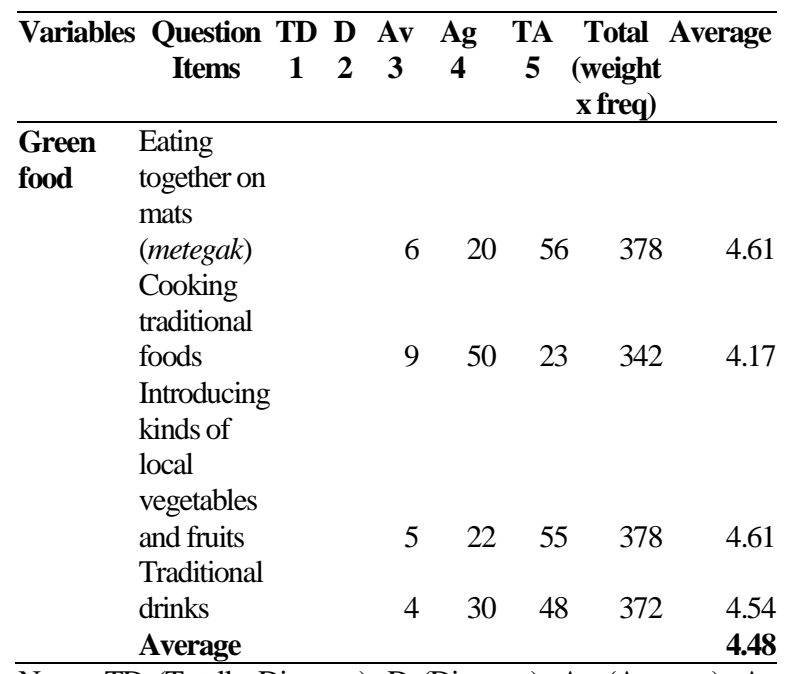

Notes: TD (Totally Disagree); D (Disagree); Av (Average); $\mathrm{Ag}$ (Agree); TA (Totally Agree); Total (weight); Freq (frequency).

Table 4

Perception on Natural Materials in Tourism Villages

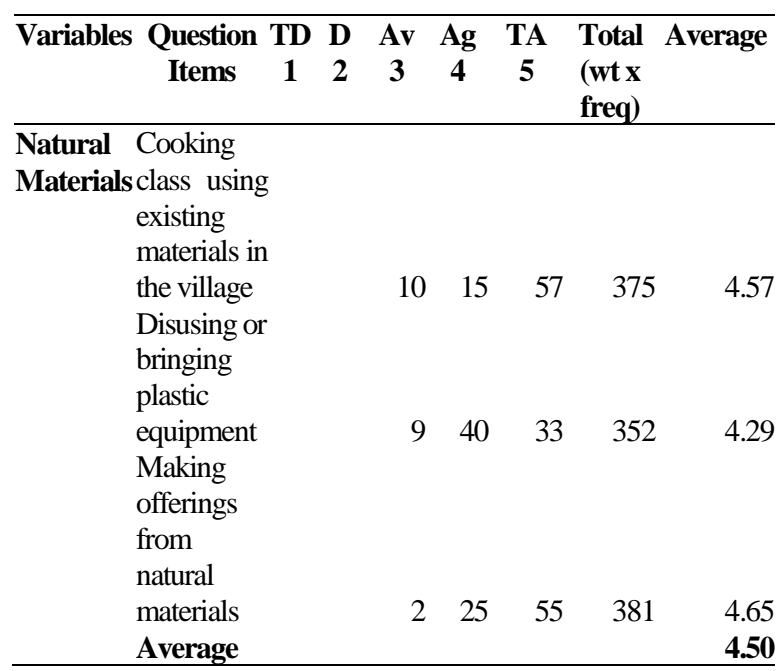

Notes: TD (Totally Disagree); D (Disagree); Av (Average); Ag (Agree); TA (Totally Agree); wt (weight); freq (frequency).

The problem of wastes becomes an important issue in the preservation of environment as well as in the development of sustainable tourism. The understanding about wastes is important for the tourism village communities as shown by the totally agree answer. The average score of the respondents' perception is 4.42 , which is close to score five or totally agree. It means that the communities are quite aware that waste management is very much attended to in 
tourism activities which are based on the green concept (Romão \& Neuts, 2017; Zhu et al., 2013; Astawa et al., 2017). The respondents' understanding about waste management, which consists of waste processing, animal dunks processing, waste vessels, kitchen wastes and composting is explicitly explained in Table 5 .

\section{Table 5}

Perception on Waste Management in Tourism Villages

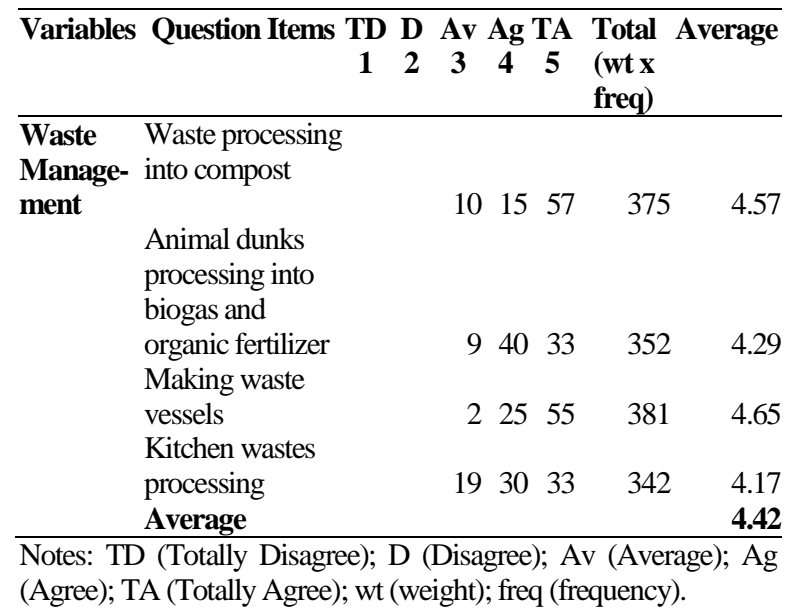

Activities related to the ecosystem, which consists of rice field cultivation, seeing into tourism spots or village environment, gain positive response. This condition is shown in the perception scoring averagely 4.52 , which is close to five (Table 6), meaning that the communities agree to the activities done in the green event. The condition which receives high support is the rice field cultivation, because village life is primarily identical with wet rice fields. This perception is similar to various past studies in which guests feel happy for being involved in wet rice field activities (Astawa, 2018; Astawa et al., 2017).

Table 6

Perception on Ecosystem in Tourism Villages

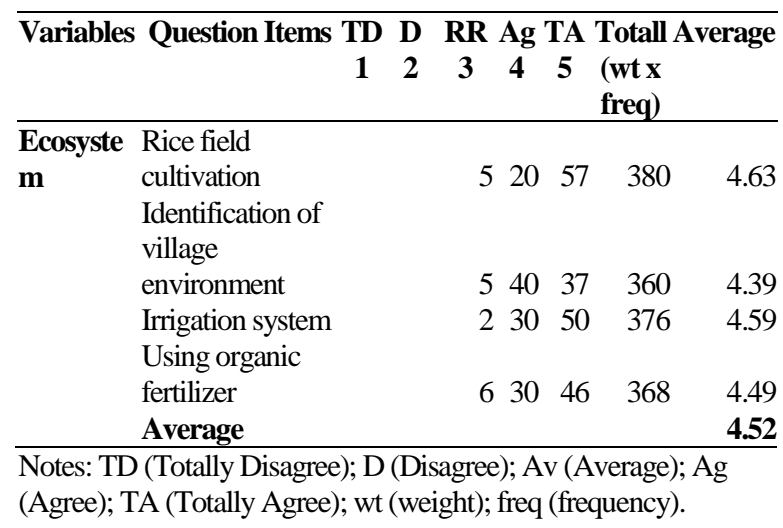

The respondents' perception on culture gives the highest support of 4.59 (Table 7) from the existing variable, reflecting the strength of their culture being adopted in every tourism activity. This condition enhances the idea that Bali tourism is a cultural tourism or that which has a strong cultural root. The culture of Tri Hita Karana has an important role in building humanity in Bali for it is blended within the religious activities and even may affect company performance (Astawa, 2013; Astawa \& Sudika, 2015; Astawa, Sukawati, Triyuni, \& Abdi, 2016).

Table 7

Perceptionon Tri Hita Karana Culture in Tourism Villages

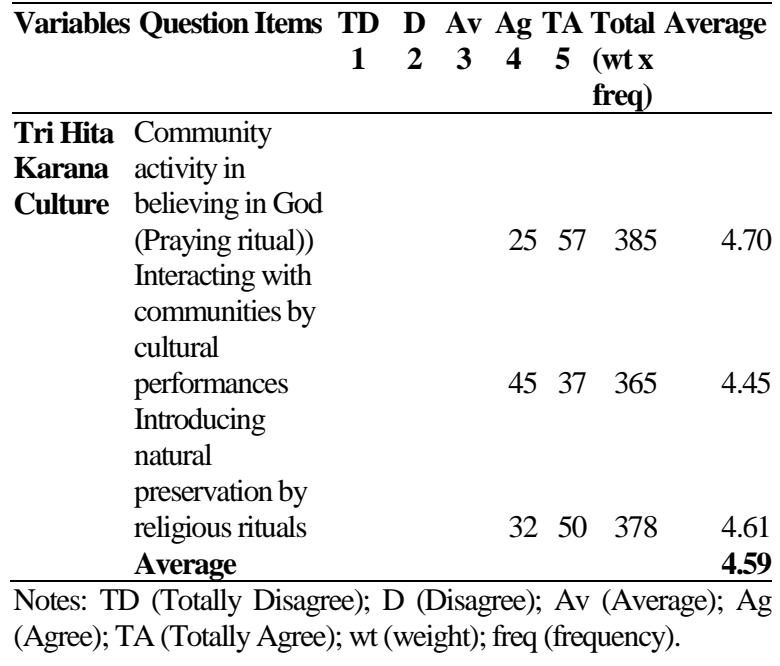

The five variables which have supported the green event can be implemented in tourism villages. The result gives motivation to the development of sustainable tourism and should have contributed to the environment, economy, and socio-culture (Romão \& Neuts, 2017). The developing attribute of the green event includes in itself cultural element in the effort of natural preservation as well as sustainable tourism. The qualitative results are green food, natural materials, waste management, ecosystem, and culture used in the green event. The result of this research gives clearer understanding to both tourists and other tourism managers to give more attention to the existing culture and its preservation.

\section{Conclusion}

The communities have understood the green event concept considerably well, because the attribute that they apply comes from their own villages in combination with the modern concept. The combination of tradition and modernity serves as glue in bringing into reality the sustainability of tourism villages which are environment friendly. The green event activity also serves as a means to enhance competitive power 
of tourism products in the villages in order to make the villages reliable and self-supporting. Village autonomy gives an opportunity to the government to realize a prosperous community.

Utilizing local culture in the development of sustainable tourism is yet rarely found in the world in the sense that it contributes to the development of the world tourism by putting in the front local, regional, and even national cultures. The result of this research will be more perfect if it is continued by another study to find the economic effect of green-based tourism activities in villages with the aim that the objective of autonomous tourism village development can be measured clearly.

\section{References}

Astawa, I. P. (2013). Ownership in the perspective of ethnomethodology at the village credit institutional in Bali. Research Journal of Finance and Accounting, 4(8), 55-62.

-_-_-_-- (2017). Pemberdayaan desa wisata Pinge melalui produk unggulan pariwisata Politeknik Negeri Bali. Bhakti Persada: Jurnal Aplikasi IPTEKS, 2(1).

(2018). The impact of harmonious culture and entrepreneurship training on loan repayment performance at microfinance in Indonesia. Asia-Pacific Management and Business Application, 6(3), 137-148.

Astawa, I. P., \& Sudika, P. (2015). The impact of local culture on financial performance in property firms in Bali. Asia-Pacific Management and Business Application, 3(2), 106-115.

Astawa, I. P., Sukawati, T. G. R., Triyuni, N. N., \& Abdi, I. N. (2016). Performance of microfinance institution in harmony cultural perspective in Bali. Procedia-Social and Behavioral Sciences, 219, 113-120.

Astawa, I. P., Triyuni, N. N., \& Santosa, I. D. M. C. (2017). Sustainable tourism and harmonious culture: A case study of cultic model at village tourism. Journal of Physics: Conference Series, 953(012057), 1-9.

Becken, S., \& Hay, J. E. (2007). Tourism and climate change: Risks and opportunities Clevedon: Channel View Publications.

Carlsen, J., \& Taylor, A. (2003). Mega-events and urban renewal: The case of the Manchester 2002 commonwealth games. Event Management, $8(1), 15-22$.

Chernushenko, D. (1994). Greening our games: Running sports events and facilities that won't cost the earth. Ottawa: Centurion Publishing \& Marketing.
Dewi, N. I. K., Astawa, I. P., Siwantara, I. W., \& Mataram, I. G. A. B. (2017). Exploring the potential of cultural villages as a model of community based tourism. Journal of Physics: Conference Series, 953(012072), 1-8.

Font, X., \& Harris, C. (2004). Rethinking standards from green to sustainable. Annals of Tourism Research, 31(4), 986-1007.

Glaser, B. G., \& Strauss, A. L. (2017). Discovery of grounded theory: Strategies for qualitative research. New York, USA: Routledge.

Gössling, S., \& Scott, D. (2008). Climate change and tourism: Exploring destination vulnerability. Tourism Review International, 12(Special Issue), $1-3$.

Hastarini, D. A. (2005). Investasi sumber daya manusia melalui pendidikan. Jurnal Dinamika Pembangunan (JDP), 2(1), 30-39.

Kapera, I. (2018). Sustainable tourism development efforts by local governments in Poland. Sustainable Cities and Society, 40, 581-588.

Kearins, K., \& Pavlovich, K. (2002). The role of stakeholders in Sydney's green games. Corporate Social Responsibility and Environmental Management, 9(3), 157-169.

Liu, J. J., Nijkamp, P., Huang, X. X., \& Lin, D. (2017). Urban livability and tourism development in China: Analysis of sustainable development by means of spatial panel data. Habitat International, 68, 99-107.

Mika, M. (2015). Sustainable tourism: A critique of the academic feasibility of the concept. Turyzm, 25(1), 9-17.

Miles, M. B., Huberman, A. M. (1994). Qualitative data analysis: An expanded sourcebook. Thousand Oaks: Sage Publications.

Murphy, P. E., \& Price, G. G. (2005). Tourism and sustainable development. In W. F. Theobald (Ed.), Global Tourism, $3^{\text {rd }}$ Edition (pp. 167193). North Holland: Elsevier Inc.

Romão, J., \& Neuts, B. (2017). Territorial capital, smart tourism specialization and sustainable regional development: Experiences from Europe. Habitat International, 68, 64-74.

Sugiyono (2010). Metode penelitian pendidikan: Pendekatan kuantitatif, kualitatif, dan $r \& d$. Bandung: Alfabeta.

Swarbrooke, J. (1998). Sustainable tourism management. Oxford: CABI.

Szymańska, E. (2013). Implementation of sustainable tourism concept by the tourists visiting, national parks. Journal of Environmental and Tourism Analyses, I(1), 64-79 
94 JURNAL MANAJEMEN DAN KEWIRAUSAHAAN, VOL. 21, NO. 1, MARCH 2019: 89-94

Weaver, D. B. (2006). Sustainable tourism: Theory and practice. London: Elsevier ButterworthHeinemann.
Zhu, Q., Li, Y., Geng, Y., \& Qi, Y. (2013). Green food consumption intention, behaviors and influencing factors among Chinese consumers. Food Quality and Preference, 28(1), 279-286. 